\title{
Türkiye'de Sık Rastlanan Salmonella Enteritidis Serovarlarına Spesifik Bakteriyofajların İzolasyonu
}

\author{
Zafer Ata \\ Askeri Veteriner Okulu ve Ĕ̈itim Merkezi Komutanlı̆̆ Gıda Kontrol ve Araştırma Merkezi Başk., Gemlik, Bursa
}

Geliş Tarihi / Received: 18.11.2018, Kabul Tarihi / Accepted: 30.11.2018

\begin{abstract}
Özet: Birçok ülkede önemli halk sağlığı sorunu olan $S$. Enteritidis, hayvanlardan ve gıdalardan izole edilen en yaygın Salmonella serotiplerinden biridir. Hayvanların bakteriyel infeksiyonlarının kontrolünde bakteriyofaj kullanımı, son yıllarda üzerinde araştırma yapılan konular arasındadır. Bu çalışmada, ülkemizde kanatlılardan en çok izole edilen Salmonella serotiplerinden biri olan $S$. Enteritidis (15 adet), bakteriyofajların konak hedef hücreleri olarak kullanıldı. Virulent bakteriyofajların izolasyonu ve zenginleştirilmesi amacıyla overlay-agar yöntemi seçildi. İzole edilen bakteriyofajların hedef bakteri suşları üzerindeki litik aktiviteleri spot test uygulaması ile belirlenerek değerlendirildi. Türkiye'nin farklı bölgelerinde bulunan ticari broyler tesislerinden $S$. Enteritidis üzerinde litik etki gösteren fajların izolasyonu için alınan toplam 78 adet örnek (tavuk dışkı, kümes atık suları, kümes altlık) bakteriyofaj izolasyonu amacıyla test edildi. Bu örneklerden toplam 22 adet $S$. Enteritidis'e spesifik fajın purifikasyonu gerçekleştirildi. Yapılan bu çalışmada, Af1-Ka ve Af3-Ka fajları, test edilen 15 adet $S$. Enteritidis suşunu sırasıly \% 78 'ini ve \% 71'ini lize ederek geniş bir konak spektrumu göstermiştir. Bu iki bakteriyofajın ileri faj karakterizasyonu ve tiplendirilmesinin yapılmasıyla, kanatlı endüstrisindeki bakterileri kontrol etmede kullanılacak etkili bakteriyofajın seçilmesi için bir temel oluşturulmasında yardımcı olabileceği kanısına varılmıştır.
\end{abstract}

Anahtar Kelimeler: Bakteriyofaj, Biyokontrol, İzolasyon, Salmonella Enteritidis

\section{Isolation of Bacteriophages Specific to Salmonella Enteritidis Serovars Common in Turkey}

\begin{abstract}
S$. Enteritidis, an important public health problem in many countries, is one of the most common Salmonella serotypes isolated from animals and foods. The use of bacteriophage in the control of bacterial infections of animals is among the topics that have been researched in recent years. In this study, $S$. Enteritidis (15), one of the most frequently isolated Salmonella serotypes in Turkey, was used as host target cells of bacteriophages. Overlay-agar method was chosen for the isolation and enrichment of virulent bacteriophages. The lytic activities of the isolated bacteriophages on the target bacterial strains were determined by spot test application. Total of 78 samples (chicken manure, poultry waste waters, poultry litter) taken from commercial broiler facilities located in different regions in Turkey was tested for isolation of phage that had a lytic effect on $S$. Enteritidis. A total of $22 S$. Enteritidis specific phages were purified from these samples. In this study, Af1-Ka and Af3-Ka phages showed a wide host spectrum by lysing $78 \%$ and $71 \%$ of the 15 $S$. Enteritidis strains tested respectively. It has been concluded that advanced phage characterization and typing of these two bacteriophages can help to establish a basis for selecting the effective bacteriophage to be used in controlling the bacteria in the poultry industry.
\end{abstract}

Keywords: Bacteriophage, Biocontrol, Isolation, Salmonella Enteritidis

\section{Giriş}

Salmonella infeksiyonları Türkiye'de kanatlı hayvan yetiştiriciliğinin en önemli problemlerinden birisidir [3]. Önemli bir zoonoz olan Salmonella infeksiyonları kanatlı hayvanlarda verim düşüklüklerine, önemli hastalık tablolarına ve ölümlere neden olmaktadır. Buna ek olarak; özellikle kanatlı hayvanlarda görülen Salmonella infeksiyonları insanlarda gıda zehirlenmelerine neden olan bulaşma kaynaklarının başında gelmektedir. Yukarıda sayılan nedenlerle kanatlilarda salmonellaların bulunması; bu hayvanların yetiştiriciliğinden halk sağlığına kadar farklı alanları ve sektörleri etkilemektedir [2].

Son yıllarda antibiyotiklere dirençli mikroorganizmalara karşı kullanmak amacıyla yapılan bakteriyofaj çalışmalarında artış olmuştur. Fajla terapi uygulamaları geçtiğimiz yüzyılın başlarında başlamıştır. 1923 yılında Gürcistan'ın Tiflis şehrinde kurulan George Elieva Enstitüsünde birçok hastalı̆̆ 1 tedavisinde bakteriyofajlar etkin olarak kullanılmaktadır [17]. Virulent Salmonella faj Felix-O1 (FO1) 1930'larda Felix ve Callow tarafindan ilk kez tanımlanmıştır [10]. Myoviridae üyesi olan bu faj, 
Salmonella spp. arasında geniş konak özelliğine sahiptir [8].

Fajlar hem gida ile temas eden yüzeylerde hem de hayvanlarda zoonoz etkenlere karşı kullanılabilmektedirler [4]. Hayvan sağlığı alanında bakteriyofajlar, broylerlerde E. coli infeksiyonlarının [14], buzağılarda E.coli'ye bağl1 ishallerin [5], piliçlerde $S$. Typhimurium'un ve $S$. Enteritidis'in bağırsaklarda ve karaciğerdeki sayılarını azaltmak için kullanılabilmektedir [4]. Ayrica $S$. Enteritidis ile infekte tavuklarda hastalığın kontrolünde kullanılan bakteriyofajlar önemli oranda bakteri sayısını azaltabilmektedir [20].

Kanatlı yetiştiriciliğinde Salmonella infeksiyonlarının kontrol altına alınması zor bir işlemdir. Kümeslerde ciddi biyogüvenlik tedbirlerinin alınmasını ve birçok antibiyotiğin kullanımını gerektirmektedir [9]. Karkas yüzeylerinde Salmonella gibi enterik patojen kaynaklı yüzey kontaminantlarının sayılarını azaltmak için farklı metotlar kullanılarak yapılan çalışmalar çok uzun yıllara dayanmaktadır. Et üretim tesislerinde yapılan hijyen amaçlı çalışmalar, geniş çapta klorlu suların veya trisodyum fosfat gibi diğer antimikrobiyal ajanların sprey tarzında uygulamalarını kapsamaktadır [21]. Salmonella enfeksiyonlarına karşı alınan pahalı ve bir o kadar da zor ve insan sağlığı açısından şüpheli olan bu uygulamalara alternatif başka çözümler gereklidir. Bakteriyosinler (nisin-Lactococcus lactis subsp. lactis), antimikrobiyal peptidler ve bakteriyofajlar bu sorunun çözümünde doğal antimikrobiyaller olarak rol oynamaktadırlar. Bu grup içinde de bakteriyofajlar doğada geniş çapta bulunmalarının yanında doğal bakteri yiyen ajanlar olarak dikkat çekmektedirler. Doğada, atık sularda ve hayvansal atıklarda bulunabildikleri gibi birçok gıda maddesinde de bulunmaktadırlar. Salmonella fajları kanatlı ekstraktlarından, kanatlı çiftlik ortamlarından ve atık su işleme tesislerinden izole edilebilmektedir. Bakteriyofajların yüksek oranda bakteri spesifik özellikleri, toksik olmamaları ve biyofilm oluşumunda birçok mikroorganizmayı kontrol edebilmeleri [16], günden güne bakteriler arasında artan antibiyotik dirençlilikleri, bakteriyofajları veteriner hekimlik ve tıp alanında daha önemli yerlere taşımıştır [4].

Literatür taramalarında diğer ülkelerde salmonelları lize eden fajlara ait birçok çalışmanın bulunmasına rağmen, ülkemizde $S$. Enteritidis'e spesifik faj çalışması bulunmamaktadır. Bu nedenle bu çalışma; ülkemizde ve dünyada sık rastlanan paratifo etkenleri arasinda yer alan $S$. Enteritidis infeksiyonlarını kontrol etmede etkili olabilecek, ülkemiz coğrafyasından izole edilen $S$. Enteritidis spesifik fajların purifikasyonları ve konakçı seçiciliğinin saptanması (bakteriyofajların Salmonella suşları üzerine olan litik etkilerinin belirlenmesi) amacıyla gerçekleştirilmiştir.

\section{Materyal ve Metot}

\section{Standart Suşlar}

Bu çalışmada, S. Enteritidis ATCC 13076 suşu, bakteriyofajların konak hedef hücreleri olarak kullanıld1. 2000-2010 y1lları arasında Uludağ Üniversitesi Veteriner Fakültesi, Mikrobiyoloji Anabilim Dalı ve Besin Hijyeni ve Teknolojisi Anabilim Dalı laboratuvarında izole edilmiş olan kanatlı hayvan orijinli toplam 14 adet $S$. Enteritidis izolatı fajların çalışmaya litik spektrumlarının belirlenmesi amacıyla dahil edildi. Ayrica Salmonella enterica spesifik Felix O1 faj1 ile $S$. Enteritidis vB-GES-Se-K1 Tiflis fajından, çalışmanın tüm aşamalarında kontrol fajı olarak faydalanıldı.

\section{Virülent Bakteriyofaj İzolasyonu}

Bursa, Adapazarı, Afyon, Balıkesir, Bandirma, Düzce bölgelerinde farklı lokalizasyonlarda bulunan kanatlı kümesi tesislerinden $S$. Enteritidis üzerinde litik etki gösteren fajların izolasyonu için al1nan tavuk dışkı örnekleri, kümes atık suları, kümes altlık olmak üzere, toplam 78 adet örnek (şubat- kasim 2015 tarihleri arasında) bakteriofaj izolasyonu amacıyla kullanıldı. Laboratuvara taşınan örnekler debris çöktükten sonra 50 ml'lik falkon tüplerde üst sıv1 santrifüj edildi $\left(4^{\circ} \mathrm{C}, 13000 \mathrm{~g}\right.$ de $\left.10 \mathrm{dk}\right)$. Santrifüj sonrası süpernatant kısmı $0,22 \mu \mathrm{m}$ geçirgenlikteki filtrelerden geçirilerek filtre edildi. Filtre edilen sıvı (filtrat) faj kaynağı olarak kullanıldı. Çalışmada kullanılan konak kültürü $37^{\circ} \mathrm{C}$ 'de Triptic Soy Broth ve Triptic Soy Agar'da çoğaltıld1, istenen bakteri konsantrasyonları spektrofotometrik olarak oluşturulan eğriye göre ayarlandı. Bakteriyofaj üremesini indüklemesi nedeniyle çalışma boyunca besiyerleri hazırlanırken, içerisine $\mathrm{CaCl}_{2}$ eklendi. 5 ml'lik hacimde Brain Heart Infusion Broth (BHIB)'a muhtemel bakteriyofaj içeren filtrattan $5 \mathrm{ml}$ ve $0.1 \mathrm{ml}$ MacFarland 0.5 konak kültürü eklendi. $37^{\circ} \mathrm{C}$ 'de 24 
saat boyunca sallayıc1 (Nüve SL 350) üzerinde inkübe edildi. Bu işlem 3 gün süreyle tekrar edildi [7].

\section{EIde Edilen Fajların Purifikasyonu (tek plak izolasyonu)}

Fajların litik aktiviteleri kullanılarak izole edilmeleri için overlay-agar $\left(\mathrm{CaCl}_{2}\right.$ 'lü yarı katı $\left.\mathrm{BHIB}\right)$ yöntemi kullanıldı ve bunun için belirli konsantrasyonlarda (MacFarland 0.5) konak kültürü (3-6 saatlik taze kültür) yarı katı agar içerisine eklendi ve bu karışım önceden hazırlanmış dip agar $\left(\mathrm{CaCl}_{2}\right.$ 'lü BHIB) üzerine döküldü. Bu sırada her bir faj stoğunun ayrı ayrı faj plaklarının daha belirgin olmalarının sağlamak amaciyla saline-magnezyum (SM) vasatı kullanıldı. Faj lizatının $10^{-6}-10^{-11} \mathrm{pfu} / \mathrm{ml}$ olacak şekilde her plak için fizyolojik tuzlu su (FTS) dilüsyonu hazırlandı. Her faj için 7 plak (petri besi yeri) olmak üzere 6 adet dilüsyon, 1 adet kontrol (fajsız) kullanıldı. Dilüsyonlar hazırlandıktan sonra her dilüsyondan ayrı ayrı hızlıca $100 \mu 1$ faj dilüsyonu overlay agara $(3 \mathrm{ml})$ eklendi ve sonra hizlica $300 \mu 1$ konak bakteri eklenerek pipetajla karıștırıldı. Kontrol plağ 1 için olan overlay agara sadece konak kültür eklendi. Bu karışım yüzeyi kurumuş dip agara döküldü. Bu işlem her dilüsyon için tekrarlandı. Kullanılacak plakların yüzeylerinin kuruması için $37^{\circ} \mathrm{C}$ 'de $1-2$ saat ters çevrilip bekletildi. Kuruyan plaklar ters çevrilerek $18-24$ saat $37^{\circ} \mathrm{C}$ 'de inkübe edildi. Ertesi gün her petrideki faj plakları tek düştüğü bir bölgeden tek bir plak steril enjektör ucuyla kesilip, steril bir tüp içerisine alındı. Bu tüpe $5 \mathrm{ml}$ BHIB eklenip iyice karıştırılarak fajların besiyerine geçmesi sağlandi. 3-6 saatlik konak kültürden (MacFarland 0.5 konsantrasyonda) tekrar $0.1 \mathrm{ml}$ alınarak bu tüp içine pipetlenerek adsorpsiyonun gerçeklessmesinden sonra $5 \mathrm{ml}$ daha sıvı besiyeri eklendi. $37^{\circ} \mathrm{C}$ 'de 24 saat boyunca sallayıcı üzerinde inkübasyonun ardından konak hücre artıklarını uzaklaştırmak için $4^{\circ} \mathrm{C}, 13000 \mathrm{~g}$ de $10 \mathrm{dk}$ 'lık santrifüj işlemi uygulandı. Bu işlemler her overlay agarda aynı morfolojiye sahip plak formasyonu görülene kadar tekrarlanarak faj purifikasyonu tamamlandi. Son olarak purifiye olarak elde edilen süpernatant, 0,22 $\mu \mathrm{m}$ porlu filtrelerden geçirilerek veya $\% 10$ kloroform eklenerek faj filtratı olarak kullanıldı. Filtrata $\% 10$ kloroform eklenerek $-20^{\circ} \mathrm{C}$ 'de bakteriyofajlar saklandi [7].

\section{Fajların Çoğaltılması}

Saf faj filtratının zenginleştirilmesi için kısaca yukarıda anlatıldığı gibi faj ve 3-6 saatlik konak bakteri, sıvı ortamda istenilen titreye ulaşıncaya kadar pasajlar yapılarak karşılaştırıldı. Titrenin belirlenmesi için son karşılaştırmaya ait faj süspansiyonunun $10^{-6}-10^{-11}$ 'e kadar FTS içerisinde dilüsyonları hazırlandı ve yine overlay-agar yöntemi kullanıldı [7].

\section{Bakteriyofajların Duyarlılıklarının Değerlendi- rilmesi}

İzole edilen bakteriyofajların hedef bakteri suşları üzerindeki litik aktiviteleri spot test uygulaması ile belirlenerek değerlendirildi. Hazırlanan dip agara fajın konak bakteri üzerinde etkili olup olmadığın anlamak amaciyla spot test uygulandı. Bu test için hazırlanan dip agara yayma plak yöntemiyle her bir bakteriden ekim yapıldı. Ekim yapılan dip agara $10^{8} \mathrm{pfu} / \mathrm{ml}$ olan 5-15 $\mu \mathrm{l}$ faj süspansiyonu eklenerek (damlatılarak) 24 saat $37^{\circ} \mathrm{C}$ de inkübe edildi. Etüvde $37^{\circ} \mathrm{C}$ 'de $18-24$ saat inkübasyon sonrasında plak formasyonları değerlendirildi. İnkübasyon sonucunda üreme olmayan alanların görülmesi fajın konak bakteri üzerine etkili olduğunu gösterdi $[7,13]$.

\section{Bulgular}

Bakteriyofaj izolasyonu amaciyla kullanılan 78 adet örnekten toplam 22 adet $S$. Enteritidis'e spesifik faj purifiye edildi (Tablo 1). Kanatlı hayvanlardan izole edilen toplam $14 S$. Enteritidis ve $1 S$. Enteritidis ATCC 13076 standart suşunun, $22 S$. Enteritidis fajlarına karşı litik aktiviteleri Tablo 2'de, litik aktiviteye sahip bakteriyofajlara ait spot test ve overlay-agar görünümleri sırasıyla Şekil 1 ve Şekil 2'de sunuldu.

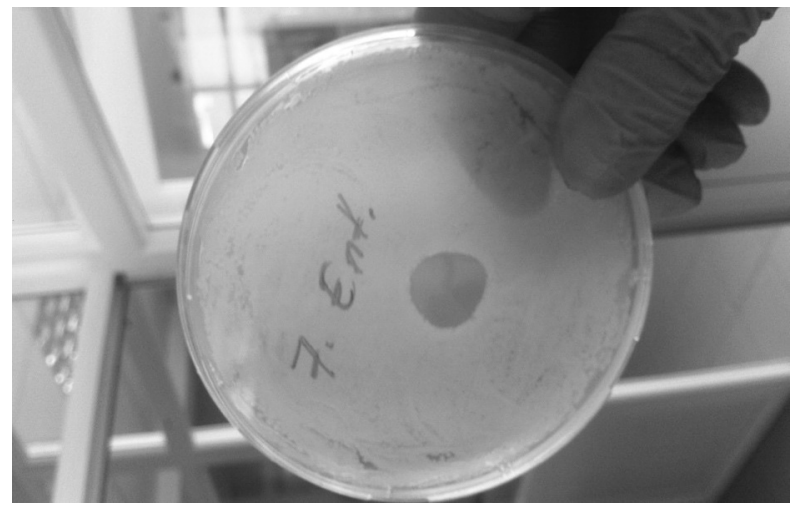

Şekil 1. Spot test görünümü 
Tablo 1. Ticari broyler kümeslerden izole edilen Salmonella Enteritidis'e özgü bakteriyofajların örneğe ve bölgelere göre dağılımı

\begin{tabular}{|c|c|c|c|c|}
\hline Orijin & $\begin{array}{l}\text { İzole edilen bakteriyo- } \\
\text { faj pozitif tavuk dışkı } \\
\text { örneği/toplam\% }\end{array}$ & $\begin{array}{l}\text { İzole edilen bakteriyo- } \\
\text { faj pozitif kümes atık } \\
\text { sIvısı örneği/toplam \% }\end{array}$ & $\begin{array}{l}\text { İzole edilen bakteriyo- } \\
\text { faj pozitif kümes altlık } \\
\text { örneği/toplam \% }\end{array}$ & $\begin{array}{c}\text { İzole edilen bakteri- } \\
\text { yofaj pozitif örnek / } \\
\text { toplam \% }\end{array}$ \\
\hline Adapazarı & $2 / 9(\% 22,2)$ & $0 / 2(\% 0)$ & $1 / 3(\% 33,3)$ & $3 / 14(\% 21,4)$ \\
\hline Afyon & $6 / 17(\% 35,2)$ & - & $3 / 8(\% 37,5)$ & $9 / 25(\% 36)$ \\
\hline Balıkesir & $0 / 8(\% 0)$ & - & - & $0 / 8(\% 0)$ \\
\hline Bandırma & $2 / 5(\% 40)$ & $1 / 2(\% 50)$ & $0 / 2(\% 0)$ & $3 / 9(\% 33,3)$ \\
\hline Bursa & $4 / 14(\% 28,5)$ & $0 / 1(\% 0)$ & $0 / 2(\% 0)$ & $4 / 17(\% 23,5)$ \\
\hline Düzce & $3 / 5(\% 60)$ & - & - & $3 / 5(\% 60)$ \\
\hline Toplam & $17 / 58(\% 29,3)$ & $1 / 5(\% 20)$ & $4 / 15(\% 26,6)$ & $22 / 78(\% 28,2)$ \\
\hline
\end{tabular}

Tablo 2. Ticari broyler kümes (tavuk dışkı, kümes atık suları, kümes altlık) örneklerinden izole edilen 22 adet $S$. Enteritidis fajının, kanatlı hayvanlardan izole edilen toplam 15 adet $S$. Enteritidis suşundaki litik aktivitesi

\begin{tabular}{|c|c|c|c|c|c|c|c|c|c|c|c|c|c|c|c|}
\hline \multirow[b]{2}{*}{ Faj Kodu ${ }^{a}$} & \multicolumn{15}{|c|}{ Salmonella suşları } \\
\hline & SE & S1 & $\mathbf{S 2}$ & S3 & S4 & S5 & S6 & S7 & S8 & S9 & S10 & S11 & S12 & S13 & S14 \\
\hline Ad1-Td & - & + & + & + & + & + & - & - & - & + & + & - & - & - & - \\
\hline Ad2-Td & + & - & + & - & + & + & + & - & - & + & - & - & - & + & - \\
\hline Ad3-Ka & + & - & - & + & + & - & - & - & + & - & + & - & + & + & + \\
\hline Af1-Td & + & - & + & - & - & - & + & + & - & - & - & + & - & - & - \\
\hline Af2-Td & - & - & + & - & - & - & + & - & - & + & - & - & + & + & + \\
\hline Af3-Td & + & - & + & - & + & - & - & + & - & - & - & + & - & - & - \\
\hline Af4-Td & + & + & + & - & + & - & - & + & - & + & - & + & + & - & - \\
\hline Af5-Td & + & - & - & - & + & + & - & - & - & - & - & - & - & - & - \\
\hline Af6-Td & + & - & - & + & + & - & - & + & + & + & - & - & - & + & - \\
\hline Af1-Ka & + & + & + & - & + & + & - & + & + & + & - & + & + & + & + \\
\hline Af2-Ka & - & + & + & - & - & + & + & - & - & - & - & - & - & - & - \\
\hline Af3-Ka & + & + & - & - & + & + & + & - & - & + & + & + & + & + & + \\
\hline Ban1-Td & + & - & - & - & + & - & - & - & - & - & + & + & + & - & - \\
\hline Ban2-Td & + & - & + & - & + & - & + & - & - & - & + & - & - & + & - \\
\hline Ban1-Kas & - & + & + & + & - & + & + & + & - & - & - & - & + & - & - \\
\hline Bur1-Td & - & - & - & + & - & - & - & - & + & - & - & + & - & - & - \\
\hline Bur2-Td & + & - & + & + & + & + & - & - & - & - & - & + & - & - & - \\
\hline Bur3-Td & + & - & + & - & - & + & + & - & - & + & + & - & - & + & + \\
\hline Bur4-Td & + & + & + & + & + & - & - & - & - & - & + & + & - & - & - \\
\hline Dü1-Td & + & - & - & - & + & - & - & + & + & - & + & + & - & - & - \\
\hline Dü2-Td & + & - & - & - & - & + & + & - & - & + & + & + & - & - & - \\
\hline Dü3-Td & + & + & - & - & - & - & - & + & - & + & + & + & - & - & - \\
\hline
\end{tabular}

a İdentifiye edilen bakteriyofajlar: Fajın izole edildiği bölge (Ad: Adapazarı; Af: Afyon; Ban: Bandırma; Bur:Bursa; Dü:Düzce), faj izolatının numarası ve örnek çeşidi (Td:Tavuk dışkısı; Ka: Kümes altıı; Kas: Kümes atık sıvısı)

SE: S. Enteritidis ATCC 13076; +: Litik aktivite pozitif; -: Litik aktivite negatif 


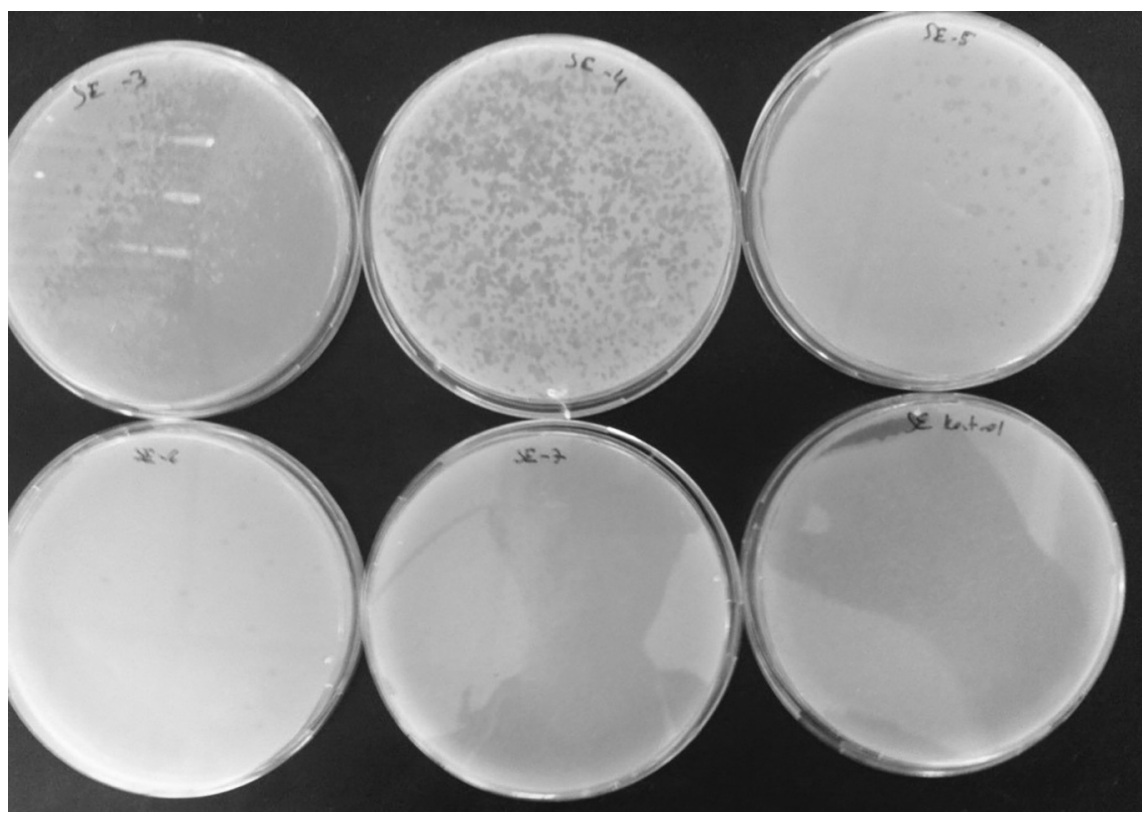

Şekil 2. $S$. Enteritidis bakteriyofaj plaklarının overlay-agar görünümleri

\section{Tartışma ve Sonuç}

Salmonelloz, ticari kümes hayvanlarını etkileyen, kümes hayvanı üretimine zarar veren ve halk sağlı̆̆1 açısından kaygı oluşturan önemli bakteriyel enfeksiyonlardan biridir. Dünyada ve Türkiye' de paratifoid Salmonella etkenleri uzun süredir insanlarda ve kanatlı hayvanlarda önemli sağlık sorunlarına ve ekonomik kayıplara neden olmaktadır. Çeşitli ülkelerde $S$. Enteritidis'e özgü bakteriyofajların izolasyonuyla ilgili yapılan araştırmalar $[4,7,20]$ bulunmasına rağmen, ülkemizde konuyla ilgili çalışma bulunmamaktadır. Bu çalışma, ülkemizde ticari broyler kümes örneklerinden (tavuk dışkı, kümes atık suları ve kümes altlıkları) $S$. Enteritidis'e özgü bakteriyofajların izolasyonun yapıldığı ilk çalışmadır.

Her konağa spesifik olmak, bakteriyofajların ortak özellikleri arasında bulunmaktadır. Bakteriyofajlar çoğu zaman sadece 1 bakteri türünü veya bir tür içinde sadece 1 serotipi enfekte ederler [1]. Bununla birlikte, bakteriyofajların bu özelliği bakteriyel infeksiyonlara karşı kontrol ve tedavi etkisini s1nırlayıcı bir faktör olarak karşımıza çıkmaktadır [6]. Araştırmacıların izole ettikleri bakteriyofajların geniş konak spektrumuna sahip olduğuyla ilgili daha önce yapılan çalışmalar bulunmaktadır. Bu çalışmada, Af1-Ka ve Af3-Ka fajlar1, test edilen 15 adet $S$. Enteritidis suşunu sırasıyla \% 78 'ini ve $\% 71$ 'ini lize ederek geniş bir konak spektrumu gösterdi.
Çin'de yapılan bir çalışmada [22], kanatlı çiftliklerinden SaFB14 fajının izole edildiği, bu fajın test edilen $39 \mathrm{~S}$. Enteritidis'i \%94,87 oranında lize ederek geniş konak spekturumuna sahip olduğu tespit edilmiştir. İzole edilen fajların konak spekturumu yönünden çalışmamız, bu çalışma ile benzerlik göstermektedir.

Atterbury ve ark. [4] kümes hayvanı işletmelerinden izole ettikleri $\varphi$ 25, $\varphi$ 28, $\varphi 37$ fajlarının, test edilen $7 \mathrm{~S}$. Enteritidis suşunun tümünde (\%100) litik aktiviteye sahip olduğunu göstererek, bu çalışmaya oranla, daha geniş konak spektrumuna sahip olduğunu rapor etmişlerdir. Bu çalışmada kullanılan hedef bakteri suşu olan $S$. Enteritis' in sayısı (15 adet) Atterbury ve ark.'nın [4] çalıșmasının ( $S$. Enteritis hedef bakteri suşu 7 adet) iki katı oranındadır. Test edilecek bakteri sayısının artması litik fajların konak spektrumu azaltmaktadır. Bunun nedeninin, konak spektrumu belirlenecek bakteri şuslarının sayıları ile litik fajların konak spektrumu arasındaki negatif korelasyon olarak düşünülmektedir.

Bakteriyofajların karakterizasyonu ve tiplendirilmesiyle (Faj genom büyüklüğü, faj genom dizi analizi, faj yapısal proteinlerinin tespiti, fajların elektron mikroskobisi vb.) farklı araştırmacıların yaptıkları birçok çalışma bulunmaktadır $[15,18,19]$. $\mathrm{Bu}$ çalışmada izole edilen fajların litik aktivitelerinin farklı $S$. Enteritidis suşlarında yakın sayılabile- 
cek özellikte olması faj izolatlarının aynı şuş olabileceği sorunu akla getirmektedir. Bu nedenle, ileri faj karakterizasyonu ve tiplendirilmesinin yapılması bu sorunun yanıtı olabileceği düşünülmektedir.

Dışkı örnekleri ve atık sular her zaman birçok Salmonella serotipine karşı litik fajların izolasyonu için büyük bir ilgi alanına sahiptir. $S$. Enteritis'e özgü bakteriyofajlar bu çalışmada, ticari broyler kümeslerinin kümes atık sıvısı, dışk1 vb. gibi toplam 78 örneğin \%28,2'sinden izole edilmiştir. Ticari broyler kümeslerinin kümes atık sıvısı, dışkı vb. örneklerinde bol miktarda bakteriyofajın bulunduğunu gösteren çalışmalar bulunmaktadır [4,12,22].

Fiorentin ve ark.'nın [11] 2005 yılında yaptıkları çalışmada kullandıkları bakteriyofajların piliçlerde $S$. Enteritidis PT4'ü yoğunluğu azalttığını göstermişlerdir. Atterbury ve ark. [4], Salmonella bakteriyofajlarının, ticari broylerlerde Salmonella suşları ile mücadele etmek için kullanabilme olanaklarını araştırmıştır. Araştırmacıların elde ettikleri sonuçlar, bu bakteriyofajların $S$. Enteritidis'in barsak kolonizasyonunu önemli ölçüde azalttığını göstermiştir [4]. Bakteriyofajların bu avantajları ve $S$. Enteritidis'e litik aktivite gösteren bakteriyofajların uygulamaları göz önüne alındığında, bu çalışmada izole edilen bakteriyofajların, $S$. Enteritidis'in neden olduğu tavukların bakteriyel infeksiyonlarını kontrol etmek için iyi terapötik ve profilaktik maddeler olma potansiyeline sahip olabileceği kanısına varılmıştır.

\section{Teșekkür}

Bu çalışmayı HDP (V)-2014-43 numaralı proje olarak Uludağ Üniversitesi Bilimsel Araştırma Projeleri Birimi (BAP) desteklemiştir.

\section{Kaynaklar}

1. Ackermann HW, Audurier A, Berthiaume L, Jones LA, Mayo JA, Vidaver AK, (1978). Guidelines for bacteriophage characterization. Adv Virus Res. 23, 1-24.

2. Akan M, (2008). Kanatllarda salmonella infeksiyonlart ve kontrolünde temel prensipler. Veteriner Tavukçuluk Derneği Mektup Ankara Dergisi 6(2), 3-4

3. Aksakal A, (2003) Bazı kanatlıların dışkılarında Salmonella türlerinin varliğ antibiyotiklere duyarlılıkları. YYÜ Vet. Fak. Derg. 14 (1), 95-101.

4. Atterbury RJ, Van Bergen MAP, Ortiz F, Lovell MA, Harris JA, De Boer A, Wagenaar JA, Allen VM, Barrow
PA, (2007). Bacteriophage therapy to reduce Salmonella colonization of broiler chickens. Appl Environ Microbiol. 73, 4543-4549.

5. Barrow P, Lovell M, Berchieri AJ, (1998). Use of lytic bacteriophage for control of experimental Escherichia coli septicemia and meningitis in chickens and calves. Clin Diag Lab Immunol. 5, 294-298.

6. Bielke L, Higgins S, Donoghue A, Donoghue D, Hargis BM, (2007). Salmonella host range of bacteriophages that infect multiple genera. Poult. Sci. 86(12), 2536-2540.

7. Carey-Smith GV, Billington C, Cornelius AJ, Hudson JA, Heinemann JA, (2006). Isolation and characterization of bacteriophages infecting Salmonella spp. FEMS Microbiol Lett. 258, 182-186.

8. Cherry WB, Davis BR, Edwards PR, Hogan RB, (1954). A simple procedure for the identification of the genus Salmonella by means of a specific bacteriophage. J Lab Clin Med. 44, 51-55.

9. Dibner JJ, Richards JD, (2005). Antibiotic growth promoters in agriculture: history and mode of action. Poult Sci. 84, 634-643.

10. Felix A, Callow BR, (1943). Typing of paratyphoid B bacilli by means of Vi bacteriophage. Brit Med J. I2, 127 130.

11. Fiorentın L, Vieira ND, Barioni WJ, (2005). Oral treatment with bacteriophages reduces the concentration of Salmonella Enteritidis PT4 in caecal contents of broilers. Avian Pathol. 34, 258-263.

12. Higgins JP, Higgins SE, Guenther KL, Huff W, Donoghue AM, Donoghue DJ, Hargis BM, (2005). Use of a specific bacteriophage treatment to reduce Salmonella in poultry products. Poult Sci. 84, 1141-1145.

13. Higgins JP, Andreatti Filho RL, Higgins SE, Wolfenden AD, Tellez G, Hargis BM, (2008). Evaluation of Salmonella-lytic properties of bacteriophages isolated from commercial broiler houses. Avian Dis. 52, 139-142.

14. Huff WE, Huff GR, Rath NC, Balog JM, Donoghue AM, (2005). Alternative to antibiotics utilization of bacteriophage to treat colibacillosis and prevent food born pathogens. Poult Sci. 84, 655-659.

15. Kang HW, Kim JW, Jung TS, Woo GJ, (2013). Wksl3, a new biocontrol agent for Salmonella enterica Serovars Enteritidis and Typhimurium in foods: Characterization, application, sequence analysis, and oral acute toxicity study. Appl Environ Microbiol. 79(6), 1956-1968.

16. Kudva IT, Jelacic S, Tarr PI, Youderian P, Hovde JC, (1999). Biocontrol of Escherichia coli O157 with O157specific bacteriophages. Appl Environ Microbiol. 65(9), 3767-3773.

17. Kutateladze M, Adamia R, (2010). Bacteriophages as potential new therapeutics to replace or supplement antibiotics. Trends Biotechnol. 28(12), 591-595.

18. Kwon HJ, Cho SH, Kim TE, Won YJ, Jeong J, Park SC, Kim JH, Yoo HS, Park YH, Kim SJ, (2008). Characterization of a T7-like lytic bacteriophage (SG-JL2) of Salmonella enterica Serovar Gallinarum Biovar Gallinarum. Appl Environ Microbiol. 74(22), 6970-6979. 
19. Lappe ND, Doran G, O'Connor J, O’Hare C, Cormican M, (2009). Characterization of bacteriophages used in the Salmonella enterica serovar Enteritidis phage- typing scheme. J Med Microbiol. 58, 86-93.

20. Sklar IB, Joerger RD, (2001). Attempts to utilize bacteriophage to combat salmonella enterica serovar enteritidis infection in chickens. J Food Saf. 21(1), 15-29.
21. Slavik MF, Kim JW, Pharr MD, Raben DP, Tsai S, Lobsinger CM, (1995). Effect of trisodium phosphate on campylobacter attached to post-chill chicken carcasses. J Food Prot. 57, 324-326.

22. Tang D, Zhang P, Zhang Q, Xue F, Ren J, Sun J, Qu Z, Zhuge X, Li D, Wang J, Jiang M, Dai J, (2018). Isolation and characterization of a broad-spectrum phage of multiple drug resistant Salmonella and its therapeutic utility in mice. Microb Pathog. doi:10.1016/j.micpath.2018.10.042. 